\title{
Effect of Gender Exploitation and Violence on Health Status of Women and Girls in Chitwan District
}

\author{
Govinda Prasad Parajuli ${ }^{1}$ \\ Sarita Chapagain ${ }^{2}$
}

\begin{abstract}
This study aimed to findout forms and causes of gender exploitation and violence as well as reveal the effect of gender exploitation and violence on the health status of women and girls. The researcher collected secondary data from District Police Office and Women Cell of the same office of Chitwan. Primary data was collected from purposive sampling method. The study reveals that majority of the victims of exploitation and violence suffers from grave physical health problem, psychological and mental health problem and reproductive health problems. Similarly, the study also reveals that the causes of gender exploitation and violence are economical, political, educational and social backwardness. From the research, it is concluded that women and girls are dominated due to lack of education, patriarchal society, polygamy society, sexual dissatisfaction and dowry. Moreover, women are discriminated from birth. This study also shows that literate women are equally victimized as well as the illiterate women and girls
\end{abstract}

\section{Key Terms: Gender Exploitation, Violence, Purposive sampling}

\section{Introduction}

World Health Organization (WHO) defined violence as "the intentional use of physical force or power threatened or actual, against oneself, another person against a group or community that either results in or has a high likelihood of resulting in injury or death psychological harm, mal-development or deprivation". Each year, more than one million people lose their lives and many more suffer from injuries due to violence. Over all, violence is among the leading causes of death worldwide for people aged 15-45 years. (World Report on Violence and Health, 2002)

An unequal gender relation pervasive in the Nepalese society has been a key in legitimizing violence against women. Besides, taboos surrounding sexual violence in Nepalese society and the general culture of silence are the biggest challenge to assess problem and endeavor accordingly making it difficult to document sexual violence without risk of causing harm to the victims. Studies in Nepal indicate that a strong patriarchal element lies at the heart of Nepalese society being reportedly at the root of social and gender discrimination. In addition, findings suggest that patriarchal attitudes and deep-rooted stereotypes that discriminate against women remain entrenched in the social, cultural, religious, economic/ political institutions, structures of Nepalese society, and in the media, thereby, legitimizing the same. Violence against women is socially accepted as 'normal' and remains high in Nepal. Furthermore, women from

1 Mr. Parajuli is Lecturer at Health Physical and Environment Department of SMC, Email: govindaparajuli@gmail.com

2 Mrs. Chapagain was M.Ed. (Health) student of SMC 
Muslim community are not culturally allowed to participate in all ranges of social activities. Some of the socially ill practices have instigated to the vulnerable status of women and children such as child marriage; dowry system: offering cash or kind during wedding; Deuki: an ancient custom practiced in the far western regions of Nepal in which a young girl is offered to the local Hindu temple to gain religious merit; Jhuma: a tradition of offering the second daughter to the monastery in the Himalaya region of Nepal; Chaupadi: tending women in segregated and unhygienic huts during menstrual period in mid-western and far-western region of Nepal, Badi: a low sub-caste traditionally practicing prostitution; Kumari: the girl who is worshipped is not allowed to go out of the temple where she is worshipped until puberty after that they are replaced by another Kumari but she should remain unmarried for life; and Kamlari: sending girl as bonded-labourer are still prevalent in Nepalese societies. Among them, Deuki, Jhuma, Chhaupadi and Kamlari experience all types of violence frequently and consequently, encounter more physical and mental health problems. In every society of Nepal, violence of girl and women is common. Basically Nepal is a patriarchal value based country. Girls and women are being victims of violence in many more forms: i.e. child marriage, girls trafficking, forced sex, sexual harassment, rape, forced marriage, marital rape forced conception, domestic violence, dowry related violence etc. These all forms of violence minimize their human rights and reproductive rights. (UNFPA 2003)

A review of studies in 20 countries found that prevalence of sexual abuse of girls ranged from 7 to 36 percent. Although any person can be sexually victimized, there are some individuals or groups of individuals who may be more vulnerable, and so appear to be over represented as victims of interpersonal violence, and of sexual violence in particular. These include unaccompanied women, children and young adults, children in foster care, physically and mentally disabled, individuals in prison or held in detention, with drug or alcohol problems, individuals with a past history of rape or sexual abuse, then involved in prostitution, individuals in abusive or dependent relationship, victims of war or armed conflict, the homeless or impoverished.

Twelve percent had experienced sexual violence at least once since Forty-three per cent of women experience sexual harassment in the workplace. Women who are employed for cash are more likely to have ever experienced sexual violence 18 percent than unemployed or women employed but not for cash 11 percent each. Women who are divorced, separated, or widowed are more likely to have ever experienced sexual violence 22 percent than currently married women 15 percent and never-married women 2 percent. Rural women are somewhat more likely to have experienced sexual violence 13 percent than urban women 11 percent. Among ever-married women, the current husband is the most commonly reported perpetrator of sexual violence 87 percent. Among all women, 3 percent have experienced sexual violence perpetrated by a stranger and 2 percent by a relative. (Nepal Demographic and Health Survey, 2011)

It is believed that the origins of violence are multi-causal. Increasingly, experts are using an "ecological model" to understand the interplay of personal, situational and socio-cultural factors that combine to cause abuse. An ecological approach to abuse argues that no one factor alone "causes" violence but rather that a number of factors combine to raise the likelihood that a particular man in a particular setting will react violently. In the ecological framework, social and cultural norms- such as those that assert men's inherent superiority over women- combine with individual level factors- such as whether a man was abused himself 
as a child- to determine the likelihood of abuse. The more risk factors present, the greater the likelihood that violence will occur.

The consequences of GBV can be broadly categorized as fatal and non-fatal. The non-fatal can be further divided as physical, sexual/reproductive, and mental or psychological; however, social consequences of violence and its impact on society must not be ignored. (Violence Against Women, 2013)

\section{Methodology}

The researcher used a qualitative and quantitative research for the study. To collect primary data and information interview schedule was used. In this study the secondary data were collected from District Police Office and District Police of Mahila Cell.

Geographically, this study was conducted at Chitwan district. Chitwan is the fifth biggest district in Nepal in terms of area $\left(238.39 \mathrm{~km}^{2}\right)$ and the total population of the district is 579,984 . Out of them 279,087 are males and 300,897 are female. The number of household of is 132,462. (Census 2011) Theoretically, this study is related to Gender exploitation and violence against women and girls and its effect on health condition of women and girls. Out of total victimized women and girls the researcher purposively selected 105 respondents. The researcher visited and interviewed those respondents for collecting necessary data by using non-probability purposive sampling method. Researcher consulted records of gender exploitation and violence cases from district police office in Chitwan, for secondary data. For the collection of primary data, the researcher used structured interview schedule as the main tools or instrument. For the development of tools, the researcher consulted research work book, journals and suggestion of supervisor in the course of preparing tools, secondary data were taken from District Police Office and District Office Mahila Cell. There altogether 19 questions in interview schedule. They are based on cross sectional method.

\section{Result and Discussion}

Distribution of Respondents According to Type of Violence: In this study area total female population was 3, 00,897 . Out of these, the population of women was $1,74,330$ and population of girl was $1,26,549$. Among total female 328 were violated. Out of violated, women were 89.10 percent and girls were 10.870 percent.

\section{Figure: 2}

\section{Total numbers of victims are classified on the basis of type of violence.}

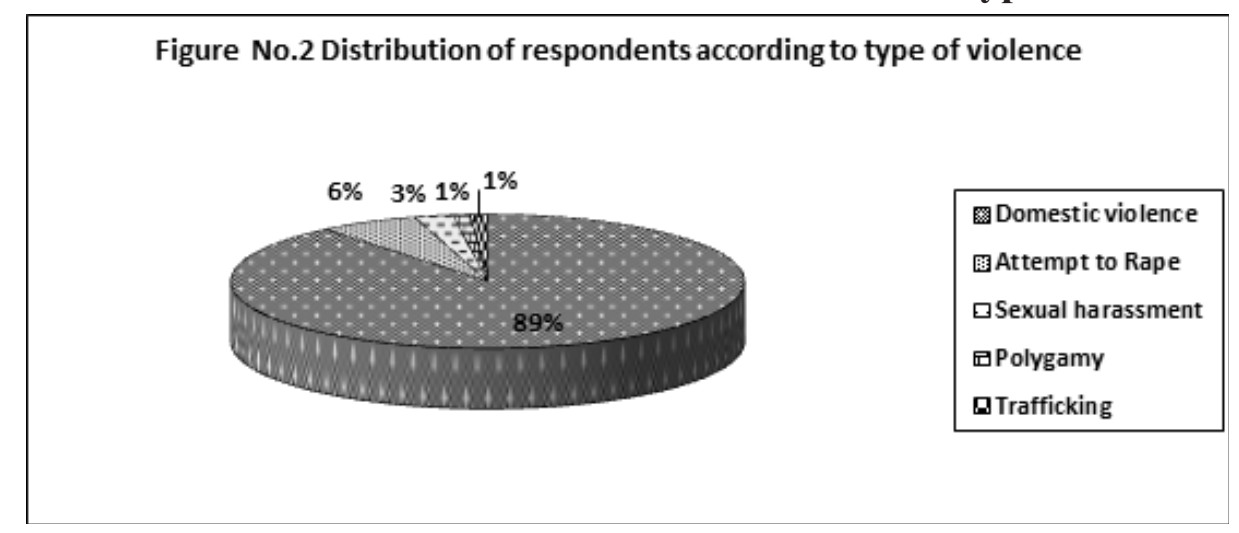

Above figure shows that highest proportion of respondents faces domestic violence 89.1 percent and Attempt 
Effect of Gender Exploitation and Violence on Health Status of Women and Girls in Chitwan District to rape 6.25 percent. The lowest proportions of violence are polygamy 1.08 percent, trafficking 1.08 percent and sexual harassment is 2.44 percent. Majority of the respondent faces domestic violence this is due to the dominating nature of family towards girls and women.

\section{Distribution of respondent according to type of domestic violence}

In this observation table, the researcher explains the four different types of domestic violence and also discusses the number of female respondents according to type of the type of domestic violence.

\section{Table 1}

Distribution of respondent according to type of domestic violence

\begin{tabular}{|l|c|c|}
\hline Type of Domestic violence & Number of Respondent & Percentage \\
\hline Psychological violence & 155 & 47.30 \\
\hline Physical violence & 121 & 36.90 \\
\hline Economical violence & 43 & 13.10 \\
\hline Sexual violence & 9 & 2.44 \\
\hline Total & $\mathbf{3 2 8}$ & $\mathbf{1 0 0}$ \\
\hline
\end{tabular}

This table reveals that maximum percent of respondent has been violated psychologically 47.30 percent. According to respondents, their husband drinking alcohol daily and always create a issue of money for fulfilling their so called addict nature and sometimes suspicious nature of their husband also causes the psychological, physical and economical violence. Due to weak laws of nation girls are violated sexually.

\section{Victimizer}

Victimizer is a person through which many girls and women are violated. Total numbers of victims are divided on the basis of kind of victimizer which is shown below.

Table 3

Victimizer

\begin{tabular}{|l|c|c|}
\hline \multicolumn{1}{|c|}{ Victimized person } & Number of victims & Percentage \\
\hline Husband & 63 & 60.00 \\
\hline Relatives & 33 & 31.43 \\
\hline Friend & 6 & 5.71 \\
\hline Work Staff & 3 & 2.86 \\
\hline Total & $\mathbf{1 0 5}$ & $\mathbf{1 0 0}$ \\
\hline
\end{tabular}

Women are mostly violated by those people who are well known to them, frequently by their husband 60 percent, relatives 31.43 percent, friends 5.71 percent and rarely by others 2.86 percent.

\section{Showing Violent Behavior}

In the table present below, out of the 105 victims 56.19 percent suffering from beating, 31.42 percent facing verbal attack, 8.57 percent raped and 3.80 percent facing trafficking. 


\section{Table 4}

Showing Violent Behavior

\begin{tabular}{|l|c|c|}
\hline \multicolumn{1}{|c|}{ Victimized Person } & Number & Percentage \\
\hline Physical (Beating) & 59 & 56.19 \\
\hline Verbal (Scolding) & 33 & 31.44 \\
\hline Sexual harassment & 9 & 8.57 \\
\hline Trafficking & 4 & 3.80 \\
\hline Total & $\mathbf{1 0 5}$ & $\mathbf{1 0 0}$ \\
\hline
\end{tabular}

\section{Causes for Being Victimized}

There is no one factor alone causes the gender based violence and exploitation but rather that a number of a factors combine to raise the likelihood that a particularly man in a particularly setting may act violently towards women. Below given flip chart diagram discuss about the different causes associated with gender based violence.

Figure No.3: Causes for Being Victimized

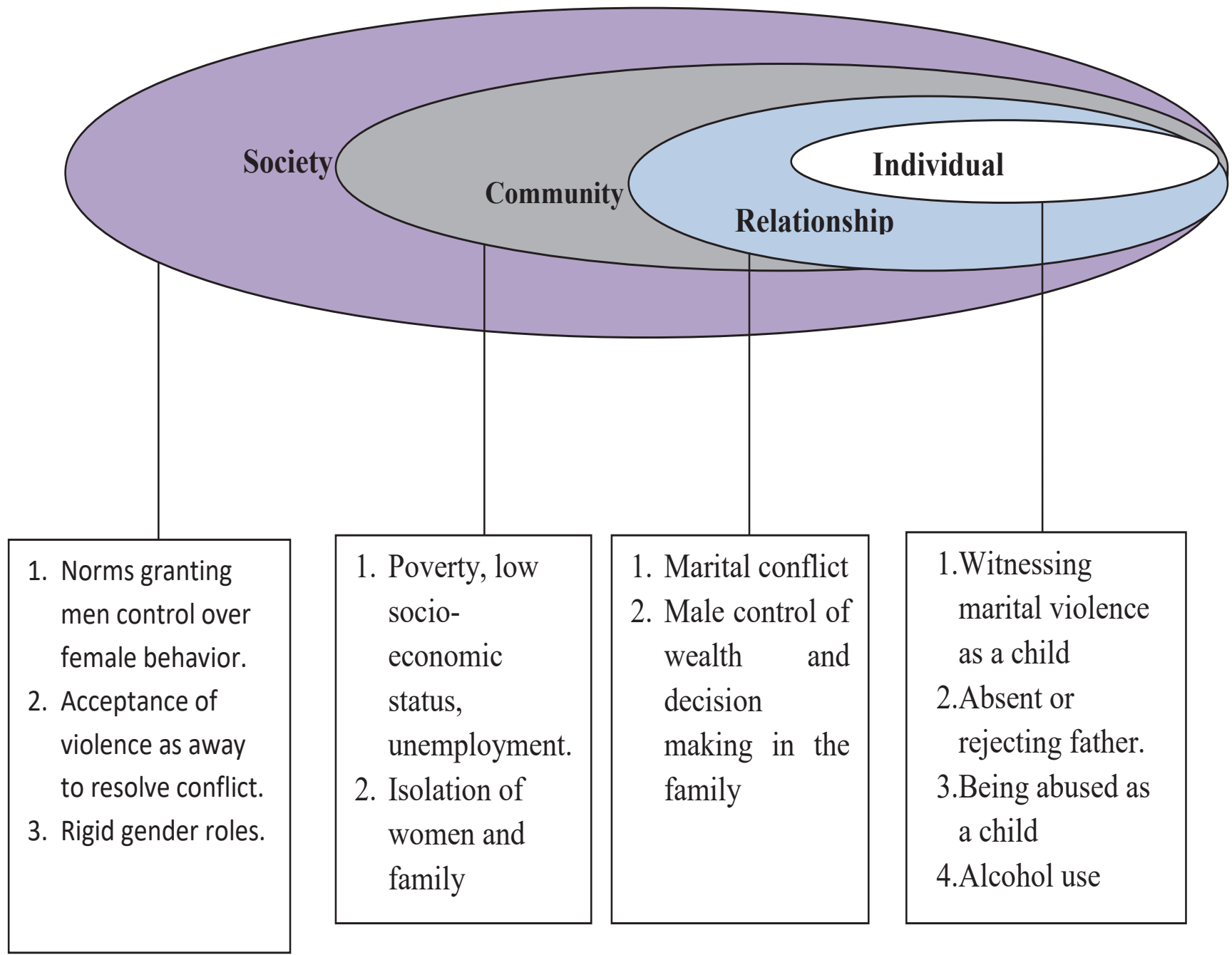


Effect of Gender Exploitation and Violence on Health Status of Women and Girls in Chitwan District

\section{Effect of Gender Exploitation and Violence}

The table present below, out of the 105 victims 56.19 percent physical health problem, 40 percent psychological and mental health problem and 4 percent reproductive health problem of victims which are suffering from gender exploitation and violence.

\section{Table 5}

Health Problem

\begin{tabular}{|l|c|c|}
\hline \multicolumn{1}{|c|}{ Type of Health Problem } & Number & Percentage \\
\hline Physical Problem & 59 & 56.19 \\
\hline Mental \& Psychological Problem & 42 & 40.00 \\
\hline Reproductive Problem & 4 & 3.80 \\
\hline Total & $\mathbf{1 0 5}$ & $\mathbf{1 0 0}$ \\
\hline
\end{tabular}

\section{Helping hands after being victimized}

According to the victims some organizations helped them for fighting against the violence, name of this organization is listed below.

Table 6

Helping hands after being victimized

\begin{tabular}{|l|c|c|}
\hline \multicolumn{1}{|c|}{ Name of the organization } & Respondent & Percentage \\
\hline Mahiti Nepal & 43 & 40.96 \\
\hline Aadarsha Griha & 32 & 30.47 \\
\hline INSEC Nepal & 13 & 12.38 \\
\hline Local communities & 17 & 16.19 \\
\hline Total & $\mathbf{1 0 5}$ & $\mathbf{1 0 0}$ \\
\hline
\end{tabular}

From field survey, 2016

Mahiti Nepal, insect Nepal and local communities helped the victim to fight for their right and against violence. Adharsha griha provides the victims after the incidence. This organization also helps to live the independent life.

\subsubsection{Issue of adjustment in society after being victimized}

The respondents said that at the initial phase they face the different kind of problem like

a) Social problem: The society people watched them with the eye of doubt and nobody gives any respect and help. This is happen because our society is male dominating and when question is raised between the husband and wife, our society always raises hands toward the women and our society always wants explanation from the women that's why it is difficult in the initial phase to adjust in the society.

b) Economical problem: According to respondent many of them are unemployed after the marriage and some doing the job of low income. They said that at the initial phase they do not have any money for food and no job but after the help of organization they are now able to live independent life.

c) Health problem: Respondent that faces the domestic violence and sexual harassment and rape said that they have health problem. Due to this they are unable to do daily activities and take a drug regularly that makes the body weak so it is difficult to adjust in the society. 


\section{Conclusion and Implication}

The research was conducted with general objective to study the health condition of women and girls who are victims of gender exploitation and violence in Chitwan. The result obtain from the research is summarized in the below points.

1. Women and girls are suffering from great physical health problem, psychological and mental health problem and reproductive health problems.

2. Cause of gender exploitation and violence are economical, political, educational and social backwardness.

3. Especially people from the lower status and uneducated people and less educated people are suffering from the violence.

4. Majority of violence are domestic and psychological. This was raised from the husband, others family members, relatives and friend.

5. Today's people follow the western culture and want to live free life that is why some girls become victims of violence these days.

6. Economic condition, male dominating society and loose laws of the nation are responsible for the cause of gender violence.

7. Women are scared from the rules of society and they love the prestige of family and do not raise any words against the criminal. That is why violence is increasing daily.

8. By not having the proper knowledge about the laws of nation and rights of women they tolerate violence.

Gender exploitation and violence against women and girl is a manifestation of the historically unequal power relations between men and women which have lead to domination and discrimination of women by men and girls by boys and to the prevention of women's full advancement. This violence against women and girls is one of the crucial social mechanism by which women are formed into a subordinate position compared with men.

In the context of Nepal, due to the lack of education many women are dominated by men through different type of violence like domestic violence, attempt to rape, polygamy, trafficking and sexual harassment. As the consequences of these violence women and girls are facing different kind of health problem such as physical, mental and psychological and reproductive health problem.

The study was conducted to identify the root cause of Gender Exploitation and Violence (GEV) and its consequences on the health of women and girls. GEV is the result of discrimination between men and women. GEV is a common problem in the Nepalese society and due to this problem women and girls have various type of health problem. There are various factors which are contributing for GEV against women and girl such as lack of education, patriarchal of the society, polygamy, sexual dissatisfaction and dowry. Consciousness and awareness of women about their legal rights is regarded as very important factor to get rid of GEV. The efficiency of legal provision and mechanism also can play vital role to control GEV but 
Effect of Gender Exploitation and Violence on Health Status of Women and Girls in Chitwan District

majority of female in Chitwan district are not so hopeful to get justice. So, majority of female keep secrets about their gender exploitation and violence related health problem.

The problem of gender exploitation and violence on the health of women and girls in Chitwan is a burning issue. This study helps to find out the type of violence and their effect on the health of women and girls. Based on finding of the study the following recommendation can be made for government, society, men and women to prevent and control the gender exploitation and violence.

While gender exploitation and violence is still wide spread and seems socially accepted in Nepali society. However, this study clearly highlights the need to create awareness about the root cause and consequences of GEV. The detrimental effect of this violence against women and girls could be prevented if potential victims and their parents were aware of the consequences of GEV. The strategies for awareness and empowerment against GEV are proposed below:

1. Advocacy for support

2. Legal reforms

3. Effective law enforcement

4 Empowerment of women and girls

\section{References}

Antena Foundation of Nepal (2016). Violence against women. www.afn.org.np/GenderSite.aspx

Ministry of Health and Population (MOHP) [Nepal], New ERA, and ICF International Inc. (2012). Nepal Demographic and Health Survey 2011. Kathmandu, Nepal: Ministry of Health and Population, New ERA, and ICF International, Calverton, Maryland

UNFPA (2003) The state of the world population the promise of equality. New York: United Nations Population Fund

Informal Sector Service Centre. (2013). Violence against Women/Girls Assessing the Situation of Nepal in 2013. Retrieved from http://www.vawhack.org/data

Krug, E.G; Dahlberg, L.L; Mercy, J.A; Zwi, A.B; \& Lozano, R. (2002). World report on violence and health. Geneva: World Health Organization 